Available online at GSC Online Press Directory

GSC Biological and Pharmaceutical Sciences

e-ISSN: 2581-3250, CODEN (USA): GBPSC2

Journal homepage: https://www.gsconlinepress.com/journals/gscbps

(RESEARCH ARTICLE)

\title{
Effect of methanol seed extract of Mucuna urens (l) medic on sexual behaviour and sperm parameters in male albino wistar rats
}

\author{
Essien Grace Emmanuel ${ }^{1,}{ }^{*}$, Udobre Aniefiok Sunday ${ }^{2}$ and Thomas Paul Sunday ${ }^{3}$ \\ ${ }^{1}$ Department of Pharmacology and Toxicology, Faculty of Pharmacy, University of Uyo, Nigeria. \\ 2 Department of Pharmaceutical and Medicinal Chemistry, Faculty of Pharmacy, University of Uyo, Nigeria. \\ ${ }^{3}$ Department of Pharmacognosy and Natural Medicine, Faculty of Pharmacy, University of Uyo, Nigeria.
}

Publication history: Received on 29 March 2020; revised on 10 April 2020; accepted on 11 April 2020

Article DOI: https://doi.org/10.30574/gscbps.2020.11.1.0078

\begin{abstract}
Mucuna urens is a shrub from the family of Fabaceae. It is claimed by the local people in Akwa Ibom State, Nigeria to weaken the penis and reduce sexual performance in men. This work was designed to study the effects of methanol extract of Mucuna urens on the sexual behaviour and sperm parameters of male albino rats. For the sexual behaviour experiment, 30 sexually mature male rats were used weighing (130-188 g). Animals were divided into 5 groups of 6 animals each. Group 1 received $5 \mathrm{mg} / \mathrm{kg}$ of tween 80, groups II, III and IV received the low dose (500 mg/kg), middle dose $(1000 \mathrm{mg} / \mathrm{kg})$ and high dose $(1500 \mathrm{mg} / \mathrm{kg})$ of the extract respectively while group $\mathrm{V}$ received $1 \mathrm{mg} / \mathrm{kg}$ of testosterone for seven days. Females used for the experiment received $17-\beta$ estradiol ( $8 \mu \mathrm{g} / \mathrm{kg}$ body weight) and progesterone (500 $\mu \mathrm{g} / \mathrm{kg}$ body weight) 48 hours and 4 hours respectively prior to the experiment. For the sperm analysis, 30 male albino rats weighing (130 -176 g) were used. Animals were divided into 5 groups of 6 animals each. The first group received $5 \mathrm{mg} / \mathrm{kg}$ of tween 80, groups II, III and IV received low dose (500 mg/kg), middle dose (1000 $\mathrm{mg} / \mathrm{kg})$ and high dose $(1500 \mathrm{mg} / \mathrm{kg}$ ) of the extract respectively for 14 days. Group V received $1 \mathrm{mg} / \mathrm{kg}$ of testosterone twice weekly. Animals were sacrificed and the sperm was analysed. The extract altered significantly some of the parameters of sexual behaviour which include an increase in mount latency and a decrease in intromission latency when compared to the negative control and positive control group. There was a dose dependent decrease in mount frequency and intromission latency. There was a decrease in the post ejaculatory interval of the extract group compared to the negative control and positive control group. There was a distortion in sperm morphology resulting in sperms with curved and bent necks and sperms with a slender body. The observed effects may in part be due to the presence of the different phytochemical constituents in the seed.
\end{abstract}

Keywords: Methanol; Seed; Mucuna urens; Sexual behavior; Sperm

\section{Introduction}

In many countries, there is little regulation of traditional medicine but the World Health Organization (WHO) coordinates a network to encourage safe and rational usage. Medicinal plants face threats such as climate change, habitat destruction and the specific threats over collection to meet market demands [1].

The use of plant-based materials including herbal or natural health products with supposed health benefits is increasing now in developed countries. However this brings attendant risks of toxicity and their effects on human health despite the safe image of herbal remedies. Herbal medicines have been in use long before modern medicine existed, yet there was little or no knowledge of the pharmacological basis of their actions and their safety [2].

\footnotetext{
* Corresponding author: Essien Grace Emmanuel
} 
Medicinal plants provide health benefits to people who consume them as medicines, financial benefits to people who harvest, process and distribute them for sale, and societal benefits such as job opportunities, taxation income and a healthier labour force which in turn boost the economy [3].

\subsection{The plant of study (Mucuna urens)}

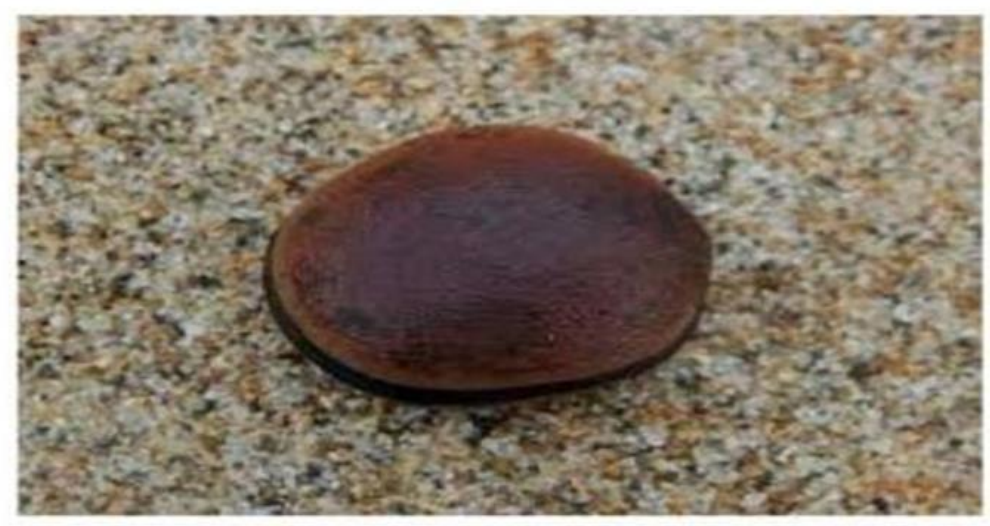

Figure 1 Mucuna urens seed

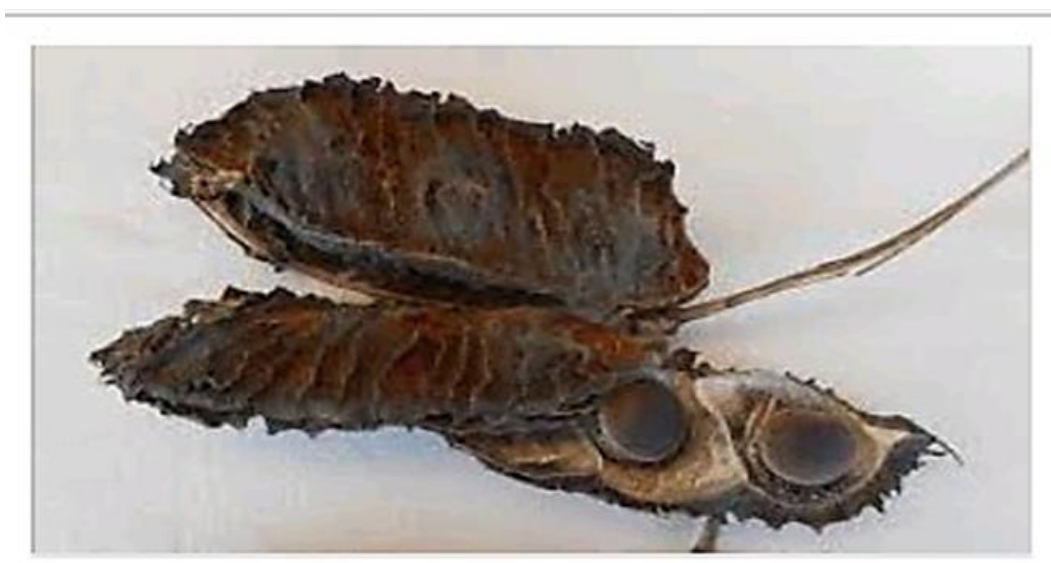

Figure 2 Mucuna urens pod

Mucuna urens is a vigorous climbing shrub, climbing over tall trees. It is harvested from the wild for local use as medicine, source of beads and fibre and it also serves as food [4] It is also known as ox-eye beans and it is a common soup thickener consumed mostly in south Eastern states of Nigeria, west Africa where Efiks, Ibibios Annangs and Igbos use as a major soup condiment for thickening. It is incorporated into normal feed for farm animals in the North due to its high protein content [5].

Mucuna urens often possess irritant hairs on the seed pods and sometimes on the flowers and other parts. These hairs consist of 1-2 small basal cells and a large needle-like top cell. The top cell breaks off easily, piercing the skin and injecting chemical compounds that are present in the hairs. The active agent that causes itching is known as mucunain [6].

Common names - Ox-Eye bean (English), Ibaba (Ibibio), Upatorok (Annang), Ukpor (Igbo), Yerepe (Yoruba), Karasau (Hausa).

Based on phytochemistry, it contains alkaloids, cardiac glycosides, tannins and saponins [14]. It is reported to contain glutamic acid, aspartic acid and leucine as the major amino acids [5]. High concentration of tannins, phytic acid, cyanogenic glycoside, oxalate and gossypol has also been reported. Toxic compounds including L-DOPA (3,4-dihydroxyL-phenylalanine), nicotine, physostigmine and serotonin are also found in Mucuna urens, and they act as its nonnutritive value [5]. Studies on the nutrient composition showed that the bean is a good source of protein (23-25\%), carbohydrate (50-56\%) and fat (8-11\%) [5]. 
The hairs from the seedpods are mixed in molasses syrup and then drank as a vermifuge to expel intestinal worms, with a chaser of rhubarb juice. The root is mixed with honey and used to combat cholera. A cataplasm of the bark and ground seed is recommended for the treatment of inguinal hernia. The seed is used for the treatment of itches. A cold water infusion of the crushed leaves is used as a wash to relieve abdominal pains. The sap from the cut stem is rubbed on sprains, rheumatic areas, contusions and sore muscles; and is also used for the treatment of children's fevers. The plant contains physostigmine, the seeds contains the amino acid L-dopa (Levodopa), which stimulates the formation of the neurotransmitter dopamine in the brain [7]. It also has anti-anaemic effect, antibacterial effect and inhibitory activity on some enzymes. Mucuna urens is claimed by the local people in Akwa Ibom State, Nigeria to weaken the penis and reduce sexual performance in men. The aim of this study is to investigate the effect of methanol seed extract of Mucuna urens on the sexual behavior and sperm integrity in male albino rats.

\subsection{Erectile dysfunction}

Erectile dysfunction (ED) is defined as the inability to achieve or sustain an erection for satisfactory sexual activity. It is the inability in achieving or maintaining an erection sufficient for penetration or sexual activity at least $50 \%$ of the time for a period of six months. [8].

Causes of Erectile Dysfunction include Conditions that reduce blood flow to the penis such as damage to the arteries, psychological conditions and social problems such as depression, trauma or injury to the pelvis such as spinal cord injury, bad habits that can reduce blood flow such as alcoholism, diseases such as hypertension and Side effects of some medications such as antihypertensive drugs . $[9,10]$.

\subsection{Aphrodisiacs}

An aphrodisiac is defined as any food or drug that arouses the sexual instinct, induces venereal desire and increases pleasure and performance. They are substances that can be derived from plants, animals or minerals [11].

\subsection{Semen}

This is the fluid produced by males for sexual reproduction and is ejaculated out of the body during sexual intercourse. Semen contains sperm. The male reproductive gametes, along with a number of chemicals suspended in a liquid medium. These sperm cells fertilize oocytes inside the female fallopian tubes [12].

Some factors that influence sperm quality include heat, physical trauma, obesity, environmental toxins, nutrition, stress, medication. Exposure to any of the temporary factors can cause up to a three months delay before sperm quality returns to normal due to spermiogenesis.

Parameters Used in Assessing Sexual Behaviour/Activity are as follows:

Mounting: It is defined as the climbing of the female by the male usually from the posterior end with the intention of introducing one organ (penis) into another (vagina). It may also be defined as the male assuming the copulatory position but failing to achieve intromission.

Mount Latency (ML): is the time interval between the introduction of the female and the first mount by the male. Mount Frequency (MF): is the number of mounts by the male on the female from the time of introduction of the female. Intromission Latency (IL): Is the time interval from the time of introduction of the female to the first intromission by the male. Intromission Frequency (IF): is the number of intromissions from the time of introduction of the female. Ejaculatory Latency: is the time interval between the first intromission and ejaculation. Post-ejaculatory interval (PEI) is the time interval between the first ejaculation and the next intromission. Penile erectile latency (PEL): This is the time interval between the first ejaculation and the next penile erection. Penile erectile frequency (PEF): This is the number of penile erections shown by the animal.

\section{Material and methods}

\subsection{Collection and identification}

The dried seeds of Mucuna urens were collected from urua oto in Ikot Ekpene Local Government Area, Akwa Ibom State in August, 2019. The identification of plant samples was done by Prof. (Mrs.) Margaret Bassey, a plant taxonomist in the Department of Botany and Ecological studies, University of Uyo, Nigeria. The voucher specimen for the sample was conserved at the faculty of Pharmacy herbarium under the reference member UUPH43 (L). 


\subsection{Ethical approval}

Approval for the use of the animals for the study was obtained from The Animal Ethics Committee of the Faculty of Pharmacy, University of Uyo Nigeria. All Animal experiments were conducted in accordance with Internationally accepted Laboratory Animal use and care of Laboratory Animals (1966) as adopted and promulgated by the National Institute of Health ( NIH) Publication Number 8523 Revised 1996 based on the Helsinki Convention and Guidelines and Rules of the Faculty of Pharmacy, University of Uyo for Animal Experimentation.

\subsection{Experimental animals}

Animals (60 male albino rats and 15 female albino rats) were obtained from Ogive Integrated Farms, Okpokoroala in Osisioma Local Government Area, Abia State. The animals were housed in a wooden cage in a well-ventilated animal house (Pharmacology Animal House Unit, University of Uyo) and kept under standard environmental conditions of 12/12hours light/dark cycle at room temperature of 250C and had free access to feed and water ad libitum.

\subsection{Extraction of plant material}

After the seeds of Mucuna urens were collected from the market. The pericarp was removed and then the seeds were cut into pieces and air dried. After drying, the pieces were pulverized and the powder was macerated in methanol for 72 hours with intermittent shaking. After 72 hours, it was filtered and the filtrate was concentrated in water bath at 45 ${ }^{\circ} \mathrm{C}$ to dryness. The concentrated extract was preserved in a refrigerator at $-4{ }^{\circ} \mathrm{C}$ and was used for the research work.

\subsection{Phytochemical Screening}

The extract was subjected to phytochemical screening using standard methods $[7,13]$.

\subsection{Pharmacological investigation}

\subsubsection{Determination of median lethal dose $\left(L D_{50}\right)$}

The median lethal dose $\left(\mathrm{LD}_{50}\right)$ of the extract was estimated using albino mice by intraperitoneal (i.p) route using the method of Lorke [15]. Fifteen healthy albino mice weighing (15-23g) were divided into five groups of three mice per group. Different doses of the extract were administered and they include $5000 \mathrm{mg} / \mathrm{kg}, 4500 \mathrm{mg} / \mathrm{kg}, 4250 \mathrm{mg} / \mathrm{kg}, 4000$ $\mathrm{mg} / \mathrm{kg}, 3000 \mathrm{mg} / \mathrm{kg}$ and $2000 \mathrm{mg} / \mathrm{kg}$. The animals were observed for manifestation of physical signs of toxicity such as writhing, decreased motor activity, decreased body/limb tone, decreased respiration and death. The number of deaths in each group within 24 hours was recorded.

The $\mathrm{LD}_{50}$ was calculated as the geometric mean of the maximum dose that produced $0 \%$ mortality and minimum dose that produced $100 \%$ mortality.

That is $L D_{50}=\left(D_{0} X D_{100}\right)$

Where $\mathrm{D}_{0}=$ Maximum dose that produced $0 \%$ mortality; $\mathrm{D}_{100}=$ Minimum dose that produced $100 \%$ mortality

\subsubsection{Effect of extract on sexual behaviour in male rats}

Male albino rats weighing 130-188g were used for this experiment. They were characterized into sexually active, sluggish and impotent. This was done by pairing sexually matured receptive female rats with male rats for 30 minutes in a Plexiglas cage at 19.00 hours, using a red bulb and observing the parameters of mount latency (ML), mount frequency (MF), Intromission Latency (ML), Intromission frequency (IF), Ejaculatory Frequency (EF), Penile Erectile latency (PEL), Penile Erectile Frequency (PEF), and Post Ejaculatory Interval (PEI) . The males were picked at random and those with the highest parameters were classified as sexually active, followed by sexually sluggish and those that did not mount at all as sexually impotent. The sexually sluggish and impotent males were discarded and the sexually active males were used for the experiments.

The sexually active males were divided into five groups of six animals per group. Group I received Tween $80(5 \mathrm{mg} / \mathrm{kg})$ orally and served as control. Groups II, III and IV received three different doses of the extract $(500 \mathrm{mg} / \mathrm{kg}, 1000 \mathrm{mg} / \mathrm{kg}$ and $1500 \mathrm{mg} / \mathrm{kg}$ orally) respectively, group $\mathrm{V}$ received testosterone $(1 \mathrm{mg} / \mathrm{kg}$ intraperitoneally) for seven days. The animals were treated with the Tween 80 , extract and testosterone respectively 6hours before commencement of the sexual behaviour experiment. Each male rat was introduced into the Plexiglas cage for 30 minutes prior to the introduction of the female rat for acclimatization. The test began when the female was introduced into the cage and 
terminated: at the end of 15 mins, or immediately after post ejaculatory intromission or if ejaculation did not occur within 15mins, or if ejaculation latency exceeded 15mins, or if the post ejaculatory internal exceeded 15mins.

Estrous was induced in the females by administration of 17 - estradiol $(8 \mu \mathrm{g} / \mathrm{kg}$ body weight $)$ and progesterone $(500$ $\mu \mathrm{g} / \mathrm{kg}$ body weight) 48 hours and 4 hours respectively before commencement of the experiment.

The following parameters were recorded accordingly: Mount Latency (ML), Mount Frequency (MF), Intromission Latency (IL), Intromission Frequency (IF), Ejaculatory Latency (EL), Penile Erectile Latency (PEL), Penile Erectile Frequency (PEF) and Post Ejaculatory Internal (PEI).

\subsubsection{Sperm analysis}

In this experiment, thirty male rats weighing $(130-176 \mathrm{~g})$ were used and divided into five groups of six rats per group. Group 1 received Tween 80 (5mg/kg orally) for 14 days and also served as control. Group II-IV received $500 \mathrm{mg} / \mathrm{kg}$, $1000 \mathrm{mg} / \mathrm{kg}$ and $1500 \mathrm{mg} / \mathrm{kg}$ (po) of the extract, respectively for 14 days. Group V received $1 \mathrm{mg} / \mathrm{kg}$ of testosterone intraperitoneally twice weekly. At the end of 14 days, all animals were sacrificed and the epididymis was carefully isolated, cut open and placed in a diluent (comprising of $5 \mathrm{~mL}$ of sodium bicarbonate, $5 \mathrm{~mL}$ of $35 \% \mathrm{ww}$ formaldehyde in $100 \mathrm{ml}$ of water). It was vigorously shaken for homogeneity and dispersal of sperm cells.

Sperm count was carried out using a Neubauer counting chamber, a microscope with magnification of $\mathrm{x} 100$, and a slide. A drop of the specimen was placed on a clean slide, the slide was placed on the Neubauer counting chamber and then examined microscopically.Sperm morphology and sperm motility were carried out by placing a drop of the specimen on the slide and then examined microscopically using magnification of x400 and x100 respectively.

\subsection{Statistical analysis}

The treated groups were compared to control and significance was determined using one-way Analysis of Variance (ANOVA), followed by Tukey-Kramer multiple comparison post-test. A probability level of $<0.05$ was considered significant. Results were expressed as mean SEM.

\section{Results}

\subsection{Phytochemical screening}

From the phytochemical screening carried out, the plant seed contained a high concentration of alkaloids, cardiac glycosides and saponins followed by tannins. Flavonoids were present in traces while anthraquinone was absent.

Table 1 Phytochemical Screening Results

\begin{tabular}{ll}
\hline Test & Inference \\
\hline Saponins & \\
Frothing test & + \\
Tannis & \\
Ferric chloride test & + \\
Alkaloids & + \\
Flavonoids & \\
a) Shinoda reduction rest & - \\
b) Sodium hydroxide test & + \\
c) Ammonia test & + \\
Cardiac glycosides & \\
a) Salkowski test & + \\
b) Lieberman's test & + \\
c) Keller killiani test & + \\
Anthraquinones & \\
a) Combine anthraquinones & - \\
b) Free anthraquinones & - \\
\hline \multicolumn{2}{c}{ Key: $\quad=$ Present } \\
\end{tabular}




\subsection{Median lethal dose $\left(L D_{50}\right)$}

Median lethal dose $\left(\mathrm{LD}_{50}\right)$ was likely to be $5000 \mathrm{mg} / \mathrm{kg}$ and $10 \%, 20 \%$ and $30 \%$ of the $5000 \mathrm{mg} / \mathrm{kg}$ were used as the low dose $(500 \mathrm{mg} / \mathrm{kg})$, middle dose $1000 \mathrm{mg} / \mathrm{kg})$ and high dose $(1500 \mathrm{mg} / \mathrm{kg})$ respectively.

Table 2 Result of Median Lethal Dose (LD50)

\begin{tabular}{lll}
\hline Dosage of Extract (mg/kg) & Mortality Rate & \% Mortality \\
\hline 5000 & $0 / 6$ & 0 \\
4500 & $0 / 6$ & 0 \\
4250 & $0 / 6$ & 0 \\
4000 & $0 / 6$ & 0 \\
3000 & $0 / 6$ & 0 \\
2000 & $0 / 6$ & 0 \\
\hline
\end{tabular}

The median lethal dose $\left(\mathrm{LD}_{50}\right)$ was about $5000 \mathrm{mg} / \mathrm{kg}$ using Lorke's method of $\mathrm{LD}_{50}$.

$10 \%, 20 \%$ and $30 \%$ of the estimated dose was used for the research work. Thus

Low dose $=10 \%$ of $5000 \mathrm{mg} / \mathrm{kg}=500 \mathrm{mg} / \mathrm{kg}$

Median dose $=20 \%$ of $500 \mathrm{mg} / \mathrm{kg}=1000 \mathrm{mg} / \mathrm{kg}$

High dose $=30 \%$ of $5000 \mathrm{mg} / \mathrm{kg}=1500 \mathrm{mg} / \mathrm{kg}$

\subsection{The effect of methanol seed extract of Mucuna urens seed on the sexual behavior of male rats}

From the results obtained, the low dose and the high dose took a longer time for mounting to occur compared to the middle dose. There was a dose dependent decrease in the mount frequency. The middle dose took a shorter time for intromission to occur compared to the low dose and high dose which took a longer time. There was a dose dependent decrease in intromission frequency. The low dose took a longer period for ejaculation to occur compared to the high dose while the middle dose had the shortest time for ejaculation to occur. There was no effect on the penile erectile latency and frequency. The low dose and the high dose took a longer time for post ejaculatory interval to occur compared to the middle dose (Table .3).

\subsection{The effect of methanol seed extract of Mucuna urens seed on the sperm motility, concentration and morphology of male rats}

\subsubsection{Sperm motility}

The middle dose had a higher effect on the sperm motility where the percentage of the non-motile sperm was higher than that of the motile sperm. The low dose and the high dose had a higher percentage of motile sperm when compared to the non-motile sperm. The low dose had a higher percentage of active sperm when compared to the middle dose and high dose.

\subsubsection{Sperm concentration}

The extract had a little or no effect on the sperm concentration and it was significantly high when compared to the standard drug but lower than the negative control group.

\subsubsection{Sperm morphology}

Here, some sperm became slender, some had a bent neck and the others were curved. The percentage of sperm with normal morphology was higher than those whose morphology was impaired. 
Table 3 Result of the effect of methanol extract of Mucuna urens seed on the sexual behaviour of male rats

\begin{tabular}{|c|c|c|c|c|c|c|c|c|}
\hline $\begin{array}{l}\text { Treatment } \\
\text { (mg/kg) }\end{array}$ & $\begin{array}{l}\text { Mounting } \\
\text { Latency (ML) } \\
\text { Mounts/sec }\end{array}$ & $\begin{array}{l}\text { Mounting } \\
\text { Frequency } \\
\text { (MF) }\end{array}$ & $\begin{array}{l}\text { Intromission } \\
\text { Latency } \\
\text { (IL) } \\
\text { Intromission/sec }\end{array}$ & $\begin{array}{l}\text { Intromission } \\
\text { Frequency (IF) }\end{array}$ & $\begin{array}{l}\text { Ejaculation } \\
\text { Latency } \\
\text { (EL) } \\
\text { Ejaculation/sec }\end{array}$ & $\begin{array}{l}\text { Penile } \\
\text { Erectile } \\
\text { Latency } \\
\text { (PEL) } \\
\text { Penile } \\
\text { Erectile/sec }\end{array}$ & $\begin{array}{l}\text { Penile } \\
\text { Erectile } \\
\text { Frequency } \\
\text { (PEF) }\end{array}$ & $\begin{array}{l}\text { Post } \\
\text { Ejaculatory } \\
\text { interval (PEI) } \\
\text { PEI/sec }\end{array}$ \\
\hline Tween 80 (5) & $0.72 \pm 0.02$ & $19.33 \pm 1.18$ & $2.59 \pm 1.40$ & $13.66 \pm 0.85$ & $6.18 \pm 0.47$ & Nil & Nil & $4.72 \pm 0.18$ \\
\hline Extract (500) & $1.11 \pm 0.33$ & $24.33 \pm 2.61$ & $1.58 \pm 0.30$ & $20.33 \pm 2.41^{c}$ & $11.04 \pm 0.60 \mathrm{~b}$ & Nil & Nil & $4.85 \pm 0.43$ \\
\hline Extract(1000) & $0.34 \pm 0.01$ & $16.0 \pm 2.50$ & $0.53 \pm 0.02 \mathrm{~b}$ & $8.00 \pm 1.52 c$ & $2.99 \pm 0.33 \mathrm{~b}$ & Nil & Nil & $3.14 \pm 0.64$ \\
\hline Extract (1500) & $2.13 \pm 0.19 \mathrm{c}$ & $8.33 \pm 0.66$ & $2.31 \pm 0.13$ & $6.66 \pm 0.20$ & $5.61 \pm 0.39$ & Nil & Nil & $4.37 \pm 0.59$ \\
\hline $\begin{array}{l}\text { Testosterone } \\
\text { (1) }\end{array}$ & $0.24 \pm 0.12$ & $29.0 \pm 1.60$ b & $3.48 \pm 0.52$ & $21.0 \pm 0.77 \mathrm{c}$ & $7.08 \pm 0.80$ & $2.42 \pm 2.42$ & $0.33 \pm 0.33$ & $6.79 \pm 0.41^{a}$ \\
\hline
\end{tabular}

Data are expressed as mean \pm SEM. significant at ap $<0.05 ; \mathrm{b}<<0.01 ; \mathrm{c} p<0.001$ when compared to control $\mathrm{n}=6$

Table 4 Result of the effect of methanol extract of Mucuna urens seed on the sperm motility, concentration and morphology of male rats

\begin{tabular}{|c|c|c|c|c|c|c|c|c|c|c|c|c|c|}
\hline \multirow{2}{*}{$\begin{array}{l}\text { Treatment } \\
\text { (mg/kg) }\end{array}$} & \multicolumn{3}{|c|}{ Motility } & \multicolumn{6}{|c|}{ Concentration (Cells X106) $/ \mathrm{ml}$} & \multicolumn{4}{|c|}{ Morphology } \\
\hline & \%Motile & $\begin{array}{l}\text { \%Non } \\
\text { motile }\end{array}$ & \%Active & $\begin{array}{l}\text { \%Sluggis } \\
\text { h }\end{array}$ & $1^{\text {st }}$ & $2^{\text {nd }}$ & $3^{\text {rd }}$ & 4th & $\begin{array}{l}\text { Total } \\
\text { average } \\
\text { X106 }\end{array}$ & $\% N$ & $\% B N$ & $\% \mathrm{C}$ & $\% \mathrm{~S}$ \\
\hline Tween 80 (5) & $81.6 \pm 3.33$ & $16.6 \pm 4.41$ & $88.3 \pm 4.41$ & $11.6 \pm 4.41$ & $31.0 \pm 1.52$ & $31.0 \pm 2.08$ & $36.0 \pm 0.88$ & $34.0 \pm 2.88$ & $33.0 \pm 2.08$ & $58.3 \pm 2.41$ & $21.6 \pm 1.66$ & $15.0 \pm 2.88$ & $11.6 \pm 1.66$ \\
\hline Extract (500) & $58.3 \pm 4.41^{\mathrm{b}}$ & $41.6 \pm 4.41^{\mathrm{a}}$ & $60.0 \pm 5.77^{c}$ & $40.0 \pm 5.77^{c}$ & $30.0 \pm 1.20$ & $29.3 \pm 0.33$ & $29.6 \pm 1.18$ & $29.3 \pm 1.76$ & $30.0 \pm 0.57$ & $36.6 \pm 2.66^{\mathrm{a}}$ & $18.3 \pm 1.66$ & $38.3 \pm 2.26^{\mathrm{c}}$ & $6.6 \pm 1.66$ \\
\hline Extract 1000) & $40.0 \pm 5.40^{\mathrm{c}}$ & $60.0 \pm 6.40^{c}$ & $33.3 \pm 2.3^{c}$ & $50.0 \pm 5.77 \mathrm{c}$ & $29.6 \pm 1.45$ & $31.3 \pm 0.88$ & $30.3 \pm 0.85$ & $32.0 \pm 1.73$ & $31.0 \pm 0.57$ & $38.3 \pm 2.26^{\mathrm{a}}$ & $18.3 \pm 1.33$ & $40.0 \pm 2.77 \mathrm{c}$ & $3.3 \pm 1.66^{c}$ \\
\hline Extract $(1500)$ & $58.3 \pm 4.41^{b}$ & $41.6 \pm 4.41^{\mathrm{a}}$ & $46.6 \pm 3.8^{c}$ & $53.3 \pm 3.81^{c}$ & $33.0 \pm 1.73$ & $31.6 \pm 1.20$ & $30.6 \pm 0.72$ & $31.0 \pm 2.04$ & $31.6 \pm 0.33$ & $48.3 \pm 1.41$ & $11.6 \pm 1.66^{a}$ & $30.0 \pm 2.88^{a}$ & $10.0 \pm 0.00$ \\
\hline $\begin{array}{l}\text { Testosterone } \\
\text { (1) }\end{array}$ & $48.3 \pm 2.28^{c}$ & $48.3 \pm 5.66^{b}$ & $26.6 \pm 3.81^{c}$ & $73.3 \pm 3.81^{\mathrm{c}}$ & $24.6 \pm 4.37$ & $25.0 \pm 2.88$ & $28.0 \pm 1.51$ & $26.6 \pm 1.45$ & $25.3 \pm 3.66$ & $53.3 \pm 1.66$ & $13.3 \pm 1.66^{\mathrm{a}}$ & $30.0 \pm 2.88^{a}$ & $0.00 \pm 0.0^{c}$ \\
\hline
\end{tabular}

Data are expressed as mean \pm SEM. significant at ap $<0.05$; ${ }^{\mathrm{p} p}<0.01$; $\mathrm{c}<<0.001$ when compared to control $. \mathrm{n}=$ 


\section{Discussion}

The people of Akwa Ibom State in Nigeria use Mucuna urens seeds as food thickener. There had been a long-aged claim that these seeds weaken penile erection, reduce sexual performance and cause infertility in man. This study investigated the claim scientifically. The result showed that the methanol extract of Mucuna urens caused sperm abnormalities such as unusual head with large acrosome, looped tail piece, mid -piece with distal droplet, pinhead, pyriform head and long hook. These observations agreed with the results of the previous study done by Etta [16].

It was also observed that as the dose of the extract increased; the mount latency (ML)

Increased and the mount frequency (MF) decreased. The animals became sluggish because it took them longer time for mount to occur. Sexual performance reduced, sperm integrity became distorted and the intromission frequency (IF) decreased. The extract recorded low sperm count, decreased sperm motility and abnormal sperm morphology.The result of the phytochemical screening showed that Mucuna urens seed extract contained tannins, saponins, flavonoids, cardiac glycosides and alkaloids.Some alkaloids such as cathinone are found to be responsible for reproductive toxicity, sexual dysfunction, decrease in plasma

Testosterone levels, decrease in sperm count, decrease in sperm motility and decrease in the number of abnormal sperm cells [17]. Previous studies had reported that cardiac glycosides such as digoxin lowered the levels of testosterone, luteinizing hormones and sexual activity [18, 19, ]. In this study Mucuna urens methanol seed extract contained alkaloid and cardiac glycosides as revealed by the result of the phytochemical screening. These bioactive constituents could be responsible for the low levels of sperm parameters and the reduced sexual activity in male albino wistar rats.

\section{Conclusion}

The study showed that the plant has a negative effect on the sexual performance and sperm integrity of the male reproductive system. The findings corroborate the claim by the local people of Akwa Ibom State that the seeds of Mucuna urens when consumed have some negative effects on the male sexual performance and sperm integrity.

\section{Compliance with ethical standards}

\section{Acknowledgments}

The technical advice of the Laboratory technologists Mrs. Akaninyene E. Akpan and Ms. Sifon Akpan is highly appreciated.

\section{Disclosure of conflict of interest}

There is no conflict of interest among the authors.

\section{Statement of ethical approval}

Approval for the use of the animals for the study was obtained from The Animal Ethics Committee of the Faculty of Pharmacy, University of Uyo Nigeria. All Animal experiments were conducted in accordance with Internationally accepted Laboratory Animal use and care of Laboratory Animals (1966) as adopted and promulgated by the National Institute of Health ( NIH) Publication Number 8523 Revised 1996 based on the Helsinki Convention and Guidelines and Rules of the Faculty of Pharmacy, University of Uyo for Animal Experimentation.

\section{References}

[1] Ahn K. (2017). "The worldwide trend of using botanical drugs and strategies for developing global drugs. BMB Reports, 50(3), 111-116.

[2] Singh A. (2016). Regulatory and Pharmacological Basis of Ayurvedic Formulations CRC Press, 4-5. ISBN 978-14987-50967.

[3] Smith-Hall C, Larsen HO and Pouliot M. (2012). People, Plant and Health: A conceptual Framework for assessing changes in Medicinal Plant Consumption. Journal of Ethnobiology. Ethnomedicine 8, 43. 
[4] Fawcett W and Rendle AB. (1910). Flora of Jamaica, British Museum.

[5] Umoren UE, Effiong 00 and Akpan IE. (2007). Journal of food Agriculture and Environment.

[6] Wiriadinata H, Ohashi H and Adema F. (2016). Notes on Malesian Fabaceae. The genus mucuna.

[7] Evans WC. (2009). Trease and Evans Pharmacognosy. 11th edition Brilliar Trinidad, Canada.Macmillan publishers, 146-194.

[8] Defilipps RA, Maina SL and Crepin J. Medical Plants of the Guianas .

[9] John P and Mulhall MD. (2008). Saving your sex life. Chicago publishing company.

[10] Kendirci M, Nowfar S and Hell Stom W. (2005). The impact of vascular risk factors on erectile dysfunction. Drugs today, 41(1), 65-74.

[11] Tom F and Lue MD. (2006). Causes of erectile dysfunction. London. Journal.

[12] Yakubu MT, Akanji M and Oladiji AT. (2005). Aphrodisiac potentials of the aqueous extract of Fadogia agrestis (Schweinf. Ex Hiern) stem in male albino rats. Asian J. Androl, 7, 399-404.

[13] Sofowora A. (1993). Medicinal plants and Traditional medicine in Africa. Spectrum Books Limited Ibadan; Nigeria.

[14] Lorke D. (1983). A new Approach to Practical Acute Toxicity Testing. Archives of Toxicology, 54, $251-287$.

[15] Etta HE, Udoh PB, Enebong EE and Okon BO. (2009). Antispermatogenic Effects of Ethanol Extract of Mucuna urens. Journal of Reproduction and contraception, 161-168.

[16] Islam MW, Tariq AM, Ageal FS, El-feraly IA and Al-Meshal IA. (1990). An evaluation of the male reproductive toxicity of cathinone. Toxicology, 60(3), 223-234.

[17] Stoffer SS, Hynes KM, Jiany NS and Ryan RJ. (1973). Digoxin and abnormal serum hormone levels. J. Am. Med, 225, 1443-1644.

[18] Neri A, Aygen M, Zekerman Z and Babary C. (1980). Subjective assessment of sexual dysfunction of patients on long-term administration of digoxin. Archives of Sexual behaviourl, 9, 343-347.

[19] Neri A, Zukerman Z, Aygen M, Lidor Y and Kaufman H. (1987). The effect of long-term administration of digoxin on plasma androgens and sexual dysfunction. Journal of Sex and Marital Therapy 6. John P and Mulhall MD. (2008). Saving your sex life. Chicago publishing company, 13, 58-63.

\section{How to cite this article}

Essien GE, Udobre AS and Thomas PS. (2020). Effect of methanol seed extract of Mucuna urens (l) medic on sexual behaviour and sperm parameters in male albino wistar rats. GSC Biological and Pharmaceutical Sciences, 11(1), 148156. 